\title{
The Fable in Service to the Reformation
}

\author{
PACK CARNES
}

One of the most interesting aspects of recent Reformation research has been the rediscovery of the popular basis for much in sixteenth-century writing. This is particularly evident in the mechanics of the popular appeal evinced by the events. Nowhere is this more striking than in the conscious use of the popular literature and popular forms then current. It was this choice of materials that helped to create and determine a significant part of the wide-spread appeal connected with writing of the day. The materials used to educate, to persuade, to convince and to fashion symbols and rallying points were for the most part well known and easily recognizable. More significantly, they were everywhere available and had been in constant and popular use for generations. The literature, and the commonplaces taken from that literature, from the Schwänke, facetiae, tales, scripture and fables - to mention only a few sources-were familiar and loved. Sixteenth-century writers found it automatic and natural to turn to these materials when laying the literature of the movement in the lap of the ordinary folk. ${ }^{1}$

One of the forms - with a foot in either camp, literature and folklore-is the Aesopic fable. At no time and in no other place did the fable find a more receptive audience than in sixteenth-century Germany. Nowhere was the ground more fertile than in Germany, and no one made better use of the fable than the Reformers.

The fable was everywhere apparent and served the Reformers in a wide variety of ways. They had, first of all, specific uses for the fable as an integral element within the general framework of educatory materials. Second, as rhetorical devices, in both complete and truncated forms (much as a proverb or as a proverbial phrase), the fable served as a particularly pointed and familiar metaphor to drive home a specific point or to allude to a previous scoring blow. This is the original, the classical Greek use of the fable, even predating the fable collection as a literary form, and is therefore nothing new with the Reformers. ${ }^{2}$ But it became a most powerful weapon in the hands of Luther, Melanchthon and many others.

Third, the fable was also widely used as a relatively refined literary genre, but unlike the contemporary humanist collections found before and 
after the Reformation and the collections to become popular in the eighteenth century, this was a genre with a bias. The fable had been didactic in nature from the beginning, and this capacity was put to very influential use by fable collectors and editors such as Burkhard Waldis and Erasmus Alberus. ${ }^{3}$

Primarily, and from a certain point of view most characteristically for the Reformers, the fable was used as a pedagogical tool. This use was largely traditional. The fable was in continuous vigorous use as a medium for teaching Latin, and had been so since the early middle ages. Aesop, together with Cato and a very few others were the primary tools for teaching Latin composition. Scores of schoolchildren memorized, paraphrased and reparaphrased the fabular corpus all through their elementary education. ${ }^{4}$ But in addition to the obvious pragmatic, straightforward value of the short Latin texts, the fable was written directly into the school curricula. Melanchthon, for example, wrote school prescriptions for the cities of Eisleben in 1525 and for Herzberg in 1538 extolling the Aesopic and the Avianus fable as the most suitable reading material in German, as well as a medium for teaching Latin. ${ }^{5}$ In the Visitationsbericht of 1528 he writes, describing the normal school day:

Die erste stunde nach mittag teglich, sollen die kinder von der musica geuebet werden, alle, klein und gros. Darnach sol der schulmeister . . . auflegen die fabulas Esopi.

[During the first hour after noon every day, all the children, large and small, are to be practiced in music. Then the schoolmaster... is to interpret the fables of Aesop.]

And then:

Morgens sollen die kinder den Esopum wieder exponieren ....

[In the morning the children are to expound their Aesop again .....]

And finally:

Wenn nu die kinder Esopum auff diese weise gelernet, sol man yhnen Terentium fürgeben, welchen sie auch auswendig lernen sollen. (Opera, 26, 92)

[When the children have learned their Aesop in this manner, they are to be given Terence, which they are also to learn by heart.]

Melanchthon took the value of the fable for granted. This attitude is clearly an inherited one. The middle ages, in fact most ages, have accepted or even insisted upon the moral aspects of the fables. The morals were clearly assumed to be reflective of the society of the time. ${ }^{6}$ For the sixteenth century in general, the fable was consonant with the scriptures, forming as a corpus a sort of secular auxiliary in short texts. This idea, together with the 
already demonstrated usefulness of the short pieces for teaching Latin and the attractiveness (in most cases) of the narratives, made the fable a natural choice for the school. This was expressed at some length by Melanchthon in his "De utile fabularum," in which the moral system to be inculcated is described as difficult for children: just as children cannot digest the coarse food and harsh drink of their parents, so also can children not digest the raw truth about life. The soft approach using fables, like mother's milk, is to be preferred. ${ }^{8}$ It is nowhere recorded whether he felt the fable to be useful with adults. ${ }^{9}$ It is not at all surprising to find Melanchthon writing the preface to one of the most extensive fable collections of all time: that of his friend Joachim Camerarius in its 1550 edition, which was reprinted in the greatly expanded edition of $1576 .^{10}$

The most spectacular occupation of the Reformers with the fable was the fable collection. Although we are concerned here essentially with the vernacular fable, mention must be made of the great Latin collections of the time. These have their roots firmly planted at once in the traditions of the so-called "Romulus collection" and the Avianus fables on the one hand, and the Italian Humanist translations out of the Greek on the other. The first had been well known in Germany for centuries; the Greek Prose Tradition, the hundreds of fabular motifs that arrived during the sixteenthcentury, hardly known at all. Working out from Heinrich Steinhöwel's collection of 1476-1477, a bilingual collection in German and Latin, and separately in Latin and in German editions, ${ }^{11}$ there is a veritable flood of collections in both languages. The Latin collections very strongly influenced the German collections in motifs, in structure and in language, although the vernacular editions produced by the Reformers took on new and radically altered forms.

Before the Reformation, but clearly helping to set up the tremendous interest in the fable in the sixteenth century, comes the Sebastian Brant augmented edition of Steinhöwel's collection. This deluxe volume was published by Pforzheim in Basel in 1501 and brought the total number of entries in the work to nearly double its original, with 300 items in the Brant version, not all of which are fables. This was followed by a German translation, perhaps as early as $1508 .{ }^{12}$ Martin Dorp began a massive Latin collection in 1512, with reprints and expanded versions appearing every year until 1520 when the hundred fables of Rinuccio d'Arezzo were added, bringing the total number of fables to nearly 200 . This collection served as the source for Erasmus Alberus' and Burkhard Waldis' German collections. ${ }^{13}$

Martin Luther's treatment of the fable is the prime example of the many uses the Reformers made of the fable. ${ }^{14} \mathrm{His}$ concern for education and his deep feelings for the fable are well known, as is his constant use of fables and fabular epimythia to drive home a particular point. $\mathrm{He}$ is now also becoming increasingly well known as a fable collector and writer. This lat- 
ter rôle is closely connected to his ideas on education. Compare Melanchthon's ideas about the fable to Luther's:

Doch mögen die, so den Esopum zum Meister ertichtet haben . . . vieleicht Ursach gnug gehabt haben, nemlich, das sie als die weisen Leute solch Buch umb gemeines Nutzes willen gerne hetten jederman gemein gemacht (Denn wir sehen, das die jungen Kindern und jungen Leute mit Fablen und Merlin leichtlich bewegt) und also mit lust und liebe zur Kunst und Weisheit gefu $\uparrow \mathrm{rt}$ wu† rden, welche lust und liebe deste gro† sser wird, wenn ein Esopus ... . fu $\uparrow$ rgestellet wird, der solche Kunst ausrede or fu $\dagger$ rbringe, das sie deste mehr drauffmercken, und gleich mit lachen annemen und behalten. ${ }^{15}$

[Still perhaps those who have styled Aesop as one of the great Masters might have had cause enough. That is, they might well have wanted to make the work available to everyone for the sake of the general good (for we see that young children and young people are easily moved by fables and tales) and so that all might be brought around to skills and wisdom with enthusiasm and joy. And this is all the greater whenever a fable is brought forth which is to expound or to demonstrate this point, so that they might notice it the better and accept it with laughter and remember it.]

Luther clearly sees the usefulness of fables as both text and context. ${ }^{16} \mathrm{Like}$ so many others, Luther very often simply made brief reference to a given fable and depended upon his readers or listeners to be familiar with the story and its inevitable point. It is significant that the fables Luther uses in this way are virtually always those found squarely in the medieval tradition, that is, those from the Avianus or the "Romulus" traditions that the sixteenth century inherited together with the "newer" fabular motifs of the Greek Prose tradition. The Reformer concerned himself with the fable in all its aspects, from the simple playful children's story to the powerful weapon of argumentum ad auctorem. In his works and in the Tischreden, he is seen rewriting the fables, telling fables to his son, advocating the use of Aesop to educate the young, and using fables (particularly those with an ass as the main character) to emphasize a point or to generalize a situation.

Luther's much-quoted letter to Melanchthon of April 23, 1530, from the Koburg is the usual starting point for a discussion of Luther's fable activity:

Pervenimus tandem in nostrum Sinai, charissime Phillippe, sed faciemus Sion ex ista Sinai aedificabimusque ibi tria tabernacula, Psalterio unum, Prophetis unum et Aesopo unum. ${ }^{17}$

[We have arrived at our Sinai, dearest Phillip, but we will make a Zion out of this Sinai and build here three tabernacles: one of the Psalter, one of the Prophets and one of Aesop.]

From this quotation and from other statements on Aesop known from his letters (dated the 12 th and the 28 th of May, 1530), ${ }^{18}$ it is clear that Luther 
intended to work on his edition of the fables as a relaxation from his more taxing work with biblical translation. It was, however, a purposeful work. This is quite clearly stated by Johannes Mathesius in the "VII. Predigt Über Luthers Leben," describing Luther's activity at the time:

\begin{abstract}
Nimmet Luther zu Koburg, gelegenheyt nach Essens, den alten Deutschen Esopum für sich und reinigt und schmuket in mit guten und derben Deutschen worten .... ${ }^{19}$

[Luther would take up the old German Aesop on occasion after dinner and cleanse.it and outfit it with good and solid German.]
\end{abstract}

It is fairly clear that one of the motivating forces that led Luther to the fable collection was a desire to make the German Aesopus (which was, in fact, Heinrich Steinhöwel's Esopus) "rein," or more fitting to be read by the young. This was of great importance, as the fable was held in high regard. In addition to his ranking Aesop together with the Psalter and the Prophets as above, he also often suggested directly that he placed these short pieces right after the scriptures themselves for their value in bringing wisdom to the reader"... wüsste ich ausser der heiligen Schrift, nicht viel bucher, die diesem uberlegen sein sollte, so man nutz, Kunst und wisheyt... . ansehen." ${ }^{20}$ It was only that the German fable editions he had known were not suitable. ${ }^{21}$ But there was another purpose. Further on in his preface we read:

Nicht allein aber die Kinder, sondern auch die grossen Fuersten und Herrn
kan man nicht bas betriegen zur Warheit und zu jrem nutz denn das man jnen
lasse die Narren die Warheit sagen. Dieselbigen koennen sie leiden und
hoeren sonst woellen oder koennen sie von keinem Weisen die Warheit leiden.
Ja alle Welt hasset die Warheit wenn sie einen trifft.
[Not only the children, but also the great Princes and Lords can not be better
deceived to the truth and to their improvement than that they be told the truth
by fools. They will listen to those same fools when they would or could not
stand to hear the truth from a wise one. Yes, everyone hates the truth when he
meets with it.]

Luther, in stressing that marvellous phrase "betriegen zur Warheit," clearly sees the functional, persuasive aspects of the fable as a rhetorical device. This thought is perhaps nowhere else so clearly expressed; his attempts to do precisely that are found everywhere in his works. ${ }^{23}$

His collection of fables was not published until some eleven years after his death, under the title Etliche Fabeln aus Esopo von M.L. verdeutscht. . . . ${ }^{24}$

How Luther handled the fables in the Steinhöwel collection has been demonstrated before, ${ }^{25}$ and a very few examples will suffice here to allow us to see the specific purpose to which the fables are being put. For Luther 
the idea of a "secular scripture" of sorts, used for functional, popular enlightenment was a very real idea. This did not slow him down from making the fables even more directly reflective of the scriptures themselves. Consider the famous fable of the Dog and the Meat, the fifth fable in Luther's fragmentary collection. ${ }^{26}$ The fable proper is not very different from Steinhöwel's version, save that Luther has characteristically left off the promythium (Amitit proprium quisque avidus alienum sumere cupit) and the standard copulative line (De tailibus Esopi fabula sic narrat), and begins directly with the narrative. The significant detail, though minor, is found in the epimythium. Although the fragmentary nature of Luther's collection admits of a number of possibilities, "Man sol sich benugen lassen, an dem das Gott gibt" ["One should be satisfied with that which God gives"] is the final version. The didacticism, naturally never far from the fable at least before the twentieth century and the modern parodies of the form, is stressed again in the new "labels" given the fables above the titles. This fable is given the lable "Geitz" [Avarice]. ${ }^{27}$

Most of the fables are treated similarly as Luther quite subtly changes the potential of the collection from a gathering of fables and entertaining stories into a moral textbook. In the second fable the text is changed only slightly: once again the promythium is left off, but the label "Hass" [hatred] is added. Luther's version is not as close to the Latin as Steinhöwel's. It tends to be freer, but never less effective. Some of the changes are very slight, but the cumulative or overall effect is more important than with Steinhöwel. For example the lamb and the wolf have relatively standard, tradition-bound questions and answers that slowly reveal the lamb is doomed. Tradition is the key. Luther does not change that greatly, but instead of answering the wolf's charge that the lamb's father had cursed him, with a German version of "nec ego tunc natus eram," Luther adds "wie sol ich (d) meins Vaters entgelten?" ["How am I to atone for my father?']- a phrase that functions similarly, but with stronger ethical, perhaps theological, overtones. These are not everywhere apparent, and it would be a distortion to suggest that the collection has been refashioned into a theological handbook, but the tendencies are clear. The moral of this fable is also different. Luther uses the proverbial "Das gewalt gehet fur recht" to drive home his moral, which begins "Wer frum sein wil, der mus leiden ..." [whoever will be pious, must suffer"].28

Luther used fables throughout his career. Wolf sees three phases in this, ${ }^{29}$ but clearly Luther never strayed from his primary use of the form as rhetorical device. The fable of the wolf and the lamb discussed above, for example, shows up first in 1521 (Werke, 7, 679). Here Luther complains that the charges made against him at his trial are contrived: that the sheep has not muddied the water for the wolf. By using the fabular tag, he describes exactly the basis upon which the charges are founded. In his Contra 
Hanswurst (1541; see Werke, 51, 469-572), Luther describes himself as the sheep who had muddied the water for the wolf, with the result that the wolf(Tetzel, the indulgence seller) went free, but Luther, the sheep, had to be eaten. This rhetorical use of the fable (examples abound ${ }^{29}$ ) was made possible naturally by the widespread use of the fable in school and at home. Indeed, the uses to which Luther put the fable were certainly consciously taught him in school. Luther used exactly those fables in his rhetorical displays that he would have learned in school, i.e., those from the "Romulus" and the Avianus collections. He does not generally use, in fact, shows no evidence of being particularly aware of, the fables from the Greek Prose tradition only just becoming available and known in Europe during his career. In Germany these fables began with Steinhöwel and continued with Brant. The Humanistic fable collections were available in Germany in the last quarter of the fifteenth century but do not become commonplace until quite a bit later, save in the works of a few humanists. ${ }^{30}$

The rhetorical use of the familiar fabular motifs was very widespread. A very large number of examples is given in Herbert Wolf's essay in Brückner, ${ }^{31}$ which also begins the much-needed work on the sermons. ${ }^{32}$ One of Wolf's examples, Mathesius' use of the Lamb and Wolf fable discussed above, will make the point:

Derwegen ein Christ das rechte Bild ist der alten Fabeln vom Wolffe und vom lamb im Esopo, so miteinander an dem Bache trincken und der Wolff dem lamb die schuld gibt, es hette jhm das Wasser getrübt. Diss ist ja eben ein Bild der armen Christenheit. ${ }^{33}$

[With regard to a Christian, the proper picture is that of the fable of the wolf and the lamb in Aesop, who were drinking together at the brook. The wolf accuses the lamb of muddying his water. This is exactly a picture of being a Christian.]

Here the paraenetic content of the fable is transformed into a straightforward image of the suffering Christian. The allegory is resolved, not into the "collected wisdom of the ages" as the fable tends to be, but into a specific example, a metaphor for the life of the Lutheran Christian. The fabular motif, again from the standard Aesopic canon known for a thousand years in Latin paraphrase throughout Europe and the common heritage of every European, is made specific, and more the parable. The polemic use to which the fable was put early on becomes in part the exemplum.

New fabular motifs are pressed into service for this function as well. The fable collections brought the new motifs together with the old. The great fable collections of the sixteenth century were all more or less Protestant, the earlier two filled with polemic. The new Protestant fable was a far cry from the traditional Aesopic one, and equally far from the original Lutheran model. 
Of the four German fable collections of the latter half of the sixteenth century, two are founded firmly on the Latin fables of Dorpius' great collection of the first quarter of the century. Burkhard Waldis' Esopus and Erasmus Alberus' Das Buch von der Tugent und Weissheit appeared within two years of each other, and mark a significant departure from the Lutheran model, and indeed from the usual fable collection. In both these collections, the fables are re-written in expansive verse, often many times the length of their Latin originals.

Waldis' collection of 400 fables, anecdotes, Schwänke and parables was published in 1518 in four books. ${ }^{34}$ His translations from Dorpius are actually free and expansive adaptations. He rarely adds an extended promythium, but the epimythia, constructed from the morals of the Dorpius fable are replete with Christian and classical allusions. In his ninth fable, for example, Waldis refers to St. Paul in a thirty-line epimythium. Other fables have Jeremiah and a large number of other figures. He often adds time and locale references to his fables, again most commonly in the epimythia, which become in effect his platform for a parade of the evils and foolishness common in his world. Although a moralist in the strictest sense, his satire and sermons never really degenerate into the polemic that is to be found in the fables of Erasmus Alberus. Waldis was a staunch converted Lutheran Reformist but demonstrates a calmness that attempts to teach by example rather than by invective. Still, Waldis' I, 90 "Vom Esel" ends with a sermonizing epimythium that is longer than the whole fable's narrative by four lines. Dorpius (1532) no. 129 has a single sentence as "moral": "Haud facile tegimus vitia, quae a puero nobiscum adoleverunt." ${ }^{\prime 35}$ Burkhard Waldis begins his corresponding 53-line moral with
Der grobe esel solt uns leren,
Dass wir selb sehen, wer wir weren,
Denn mancher jetzt hoch einher fert,
Tut sich herfür, als sei er glert,
Sagt, wie er könn griechisch, ebreisch,
Latein, arabisch und chaldeisch,
Schwatzt vil davon beim gmeinen man,
Der sicht in vor ein doctor an.
[The crude ass ought to teach us that we ought to see ourselves as we ought to be. Many are arrogant, and act as though they are learned. They give out that they are versed in Greek, Hebrew, Latin, Arabic, and Chaldean and prattle on about these with ordinary people who see him as a teacher.]

Alberus' use of the same fable (no. 33) is quite different, as easily seen from his choice of title: "Vom Bapstesel." Here the fable is nothing more than a springboard for invective against false (i.e. non-Lutheran) teaching. His epimythium begins 
Also gehts zu in dieser Welt, Das man die für die besten helt,

Und uber all gelerten preist,

Die nie kein tugendt han beweist,

So sehr geliebt der falsche schein

Dem Volck, das muss der Teuffel sein,

Ja viel mit ihrer falschen kunst,

Erwerben grosser Herren gunst,

Solch schelmen heisst man Suddeler,

Sie wissen nichts von guter ler,

Und doch so jemerlich betriegen

Das arme Volck, mit ihrem liegen. ${ }^{36}$

[Such is the way of the world, that he who has never shown any virtue is considered the best and is praised above all scholars. The false ones seem to be so beloved of the people that they must be the devil himself; indeed they gain often the favor of great Lords with their evil cunning. Such tricksters are called Suddeler. They know nothing of proper teaching and still they confound the poor people so terribly with their lies.]

There are many other differences. Most significantly, Waldis followed tradition in naming his collection Esopus; the difference in emphasis is clear in Alberus' choice: Das Buch von der Tugent und Weissheit, nemlich, Neunundviertzig Fabeln, der mehrer Theil aus Esopo gezogen, und mit guten Rheimen verkleret ... (1550). Fable writing had been an activity of his youth, and Alberus had published a few of these previously. Alberus knew Luther well and might have been spurred on in his fable writing by Luther himself. ${ }^{37}$

Alberus is a moralist. Whereas the preachers used fables in their sermons, Alberus preaches with his fables. His fables are written with the practical purpose of teaching proper conduct, and there seems to be no room for anything else in his design. The fables are to be used: ... "das die leute dadurch gebessert werden" (Branue, p. 2) he says in his introduction. Furthermore there is historical precedent for this, since, indeed, the Prophets and "heilige Leut"- - even Jesus-used parables (there seems to be no generic distinction made here at all, and none intended) in their teaching (Branue, pp. 2-3). One must, however, take care. This teaching does not come from just any fable, for

... der Teuffel (hat) auch seine Fabeln, als der Stationierer und Mönche lügen im Bapstumb, Mahomets Alcoran, und der Juden Talmüdische Fabeln, die niergend zu dienen, dann das sie des Teuffels Reich mehren, und die Leute von Gott und der warheit führen.

[... the devil also has fables, as the scriveners and monks lie in the papacy, in Mahomet's Koran and in the Jewish Talmudic fables, which serve to increase the kingdom of the devil and to lead people away from God and from the truth.] 
Correlating the papacy, Islam, and Judaism shows his programmed intent. He continues:

Aber unsere Fabeln dienen dem, der sie gegeben hat, und preisen sein lob und ehr, leren tugend und gute sitten, und bringen grossen nutzen. (Braune, 2-3) [But our fables serve him who has given them out and extol his praise and honor and teach virtue and good morals and are of great practical value.]

Thematically, the fables are designed for a moral end, one in service to the faith as defined by Alberus and ultimately by Luther. The fables do precisely what Luther intended the fable collection to do: they present the issue in such a manner that the reader or listener is, in effect, "beguiled" or "deceived" into the truth. Alberus is a Lutheran, however, and the extensive digressions satirize other Protestants as well as the Roman Church and other targets. Almost all this is digression, and the actual narrative, the essential motif, of the fable is often submerged, if not actually lost sight of completely, in a number of cases. In three, he digresses in totally different and unrelated narratives.

Alberus' nineteenth fable, for example, rambles on, describing a particular area's topography, giving the course of its rivers and then makes mention of the eminent Protestants found there. Only then does the piece get to the fable proper, "Crab and his Mother," a well-known Avianus fable. The motif involves the older crab admonishing the younger crab to walk straight and not sideways. The irony is obvious: clearly Alberus did precisely what the fable teaches us not to do, and the younger crab answers that he would in fact walk straight and not sideways, if the older crab would but show him how.

It is in the "morale," however, that Alberus demonstrates both his intention not to be satisfied with the limited scope of his source and his ultimate purpose in writing the fables. His morals are to the point, without the metaphorical quality of most fable writers-including Luther-before him. The morals are typically not proverbial and general. He does not usually stay within the framework of the universals expressed within the copulative "Fabula docet..." or "This fable is specifically meant for those who...," but generally follows with specific examples buttressed with classical or biblical quotations.

The last of the great German fable collections of the sixteenth century is the Alte Newe Zeitung von der Welt Lauff. This collection was first published in 1592 and contains 54 highly varied fables. ${ }^{38}$ Much is different here. These fables are neither selected for, nor written to, the same fashion as the collections of the mid-century. The fables in Rollenhagen's collection are carefully structured in a tripartite format: a relatively simple promythium, always entitled "Weltlauff" and containing a generalized moral; 
followed by the fabular motif called an "Exempel"; and finally an epimythium entitled "Lehre" and consisting generally of proverbial expressions. This is a unique and somewhat idealized form. The classical fable is typified by the central short narrative with an occasional promythium or epimythium. ${ }^{39} \mathrm{~A}$ rare Phaedrine fable might have all the possible structural elements-promythium, copulative line, narrative, copulative line and epimythium - but this is clearly the exception. The medieval fable strongly promoted the epimythium, the "moral tag"; so much so that it is possibly the single most obvious feature of the fable today. The Rollenhagen fable is carefully structured toward a synthetic model more reminiscent of the medieval fable than his mid-century predecessors. The longwinded, digressive epimythia are gone, and with them has gone most of the polemic.

This unique collection stands at the end of the sixteenth-century fable tradition. The history of the fable in service to the Reformation is very nearly a history of fable activity during the century, a century marked by decades of dedication to the form, to the collecting and editing of fables, and to pressing the fable into service as a rhetorical device and teaching tool. It is a history of the special circumstance of the writing of the fable as fable, that is, as a form of literature in its own right and as a starting point for the drama and for other forms. This is an essential element of the literature in sixteenth-century Germany and needs much research. The roots of the eighteenth-century's emphasis upon the fable as a literary genre are to be found here.

This is an age that expected and obviously enjoyed didactic materials and a rather large number of writers used fables in their works. Luther of course used them generally to make a point, so also Johann Eberlin von Günzberg, Thomas Murner and a host of others from the earlier part of the century. In the later decades, Johannes Fischart uses a number of fables in various works, all strongly Protestant in flavour. His fables are clearly those of the oral tradition and not dependent upon any single collection. He rarely tells the full fable, but simply gives a line or two recalling the motif, and assumes the reader is able to recognize the narrative and make the application desired.

Such is the course of the fable in the sixteenth century. It had been carried through the Middle Ages by the era's love for the didactic and by the pedagogical possibilities inherent in the short form. It was re-discovered and brought to bud by the Humanists who clearly saw new possibilities in the re-discovery of the Greek Prose tradition for the philological inclinations of that movement. The Reformers drew from the traditional materials and attitudes, and from the Humanists' revitalization of the form as they found the short, moralistic, pieces of "secular scripture" most admirably suited to their purposes. 


\section{Notes}

1 In the forefront here stands the monumental Volkserzählung und Reformation, ed. Wolfgang Brückner (Berlin: Erich Schmidt, 1974), especially the Brückner essay, pp. 13-123, and Herbert Wolf s contribution, pp. 705-756. The volume is outfitted with an extensive bibliography and an index of motifs. The beginnings of this sort of study might be traced to Amold Erich Berger's Lied-, Spruch- und Fabeldichtung im Dienste der Reformation, Deutsche Literatur in Entwicklungsreihen, Reihe Reformation, no. 4(Leipzig: Reclam, 1938), although in spite of the promising title, this work is little more than a collection of songs and popular pieces that support the Protestant cause. Wolfgang Kosack has added much to our concept of "Volkserzählung," in "Der Gattungsbegriff 'Volkserzählung, " Fabula, 12 (1971), 18-47, and a good start into the special problems of popular materials in their relationship to the Humanists can be found in Josef Schmidt, "Humanism and Popular Culture," The Renaissance and Reformation in Germany: An Introduction, ed. Gerhart Hoffmeister (New York: Frederick Ungar, 1977), pp. 177-188. Much more specific is Hans Trümpy's essay "Theorie und Praxis des volkstümlichen Erzählens bei Erasmus von Rotterdam," Fabula, 20 (1979), 239-248.

2 See especially Ben Edwin Perry's Aesopica (Urbana, Illinois: The University of Illinois Press, 1952) and his Babrius and Phaedrus in the Loeb Series (Cambridge, Mass.: Harvard University Press, 1956). The former is also used as the locus classicus of all fables mentioned below. The most extensive evaluation of the classical use of the fable and its theoretical underpinnings from Aristotle's Rhetoric through the great classical collection is also by Perry: "The Origin of the Epimythium," TAPA, 71 (1940), 391-419 and his "Demetrius of Phalerum and the Aesopic Fables," $T A P A, 93$ (1962), 287-345, and the literature cited there.

3 This is, of course, no different from the inherent didacticism of the fable collections of the Middle Ages. The difference is one of emphasis, with the morals expressed being channeled into a single type of system, a narrowly defined format and theme, rather than the more generalized "collective wisdom of the ages," or simple common sense content of more traditional collections.

4 Fables are still used this way, specifically for Latin, but also for a multiplicity of other pedagogical functions. See Richard Dithmar, Die Fabel: Geschichte-Struktur-Didaktik, 3rd Edition (Paderborn: Schöningh, 1971) and his citations, and Maria Eschbach, Die Fable im deutschen Unterricht (Paderborn: Schöningh, 1972). For the latest description of the school curriculum in Luther's schools, see Gerald Strauss, Luther's House of Learning (Baltimore: Johns Hopkins Press, 1978).

5 Phillipi Melanthonis Opera quae supersunt omnia, ed. Carl Bretschneider and Heinrich Bindseil, 28 vols. (Halle and Braunschweig: Schwetschke, 1834-1860; now reprinted, New York: Johnson Reprint Corp., 1963) is the source for all Melanchthon quotations below. These sections are found in volume 26, pp. 30-95.

6 Arno Schirokauer, "Die Stellung Äsops in der Literatur des Mittelalters," Festschrift Wolfgang Stammler, reprinted in Fritz Strich, Germanistische Studien (Hamburg: Hauswedell, 1957), 396415 , suggests that this is not the case in the Middle Ages, although this idea has been convincingly put to rest by Klaus Grubmüller in Meister Esopus: Untersuchungen zu Geschichte und Funktion des Fabels im Mittelalter (Munich: Artemis, 1977). Schirokauer, on the other hand, has suggested that Luther's collection be likened to a Biblia pauperum, perhaps for children, in total disregard of the preface to that collection. See Schirokauer, "Luthers Arbeit am Äsop," MLN, 62 (1947), 73 84.

7 Opera omnia, 11, 116-120.

8 Opera omnia, 11, 118.

9 Luther, on the other hand, clearly does. See below for Luther's use of the phrase "betriegen zur warheit" and compare Klaus Doderer, "Über das 'betriegen' zur Wahrheit: Die Fabelbearbeitung Martin Luthers," Wirkendes Wort, 14(1964), 379-388. Doderer demonstrates that for Luther the fables serve to teach true human relationships in society. See also "Die Grundlagen der deutschen Fabeldichtung des 16. und 18. Jahrhunderts," Archiv für das Studium der neueren Sprachen und Litteraturen, 160 (1931), 19-33.

10 For editions of the Camerarius' collection, see Pack Carnes, “Heinrich Steinhöwel's Esopus and the Corpus of Aesopica in Sixteenth-Century Germany" (dissertation, UCLA, 1973), and Paul 


\section{8 / Renaissance and Reformation}

Thoen, "Les grands recueils ésopiques latins des xve et xvie siècles et leur importance pour les littératures des temps modernes," Acta conventus neo-latini Lovaniensis; Proceedings of the First International Congress of Neo-Latin Studies, ed. I. Ijsweijn and E. Keßler(Munich: Fink, 1973), 659-679, especially p. 664.

11 See Carnes, "Heinrich Steinhöwel," for editions and imitations.

12 So Goedeke, Grundriss. I can find no other evidence of such an edition. The 1535 edition, on the other hand, is well known.

13 See Thoen, "Les grands recueils ésopiques...," pp. 661-664; and especially his complete review of Martin Dorp's collection in "Aesopus Dorpii: Essai sur l'Esope latin des temps modernes," Humanistica Lovaniensia, 19 (1970), 241-316.

$14 \mathrm{He}$ is clearly the most studied. In addition to the Schirokauer, Kayser and Doderer essays, there is also W. von Both's dissertation, Luther und die Fabel (Breslau, 1927) and August Götze, "Luthers Fabeldichtung," The Germanic Review, 5 (1930), 127-131; as well as the introduction to Ernst Thiele's edition, Luthers Fabeln (Halle: Niemeyer, 1888), iii-xvi and Herbert Wolf's section on the fables in Martin Luther (Suttgart: Metzler, 1980), pp. 145-148.

15 From the preface to the collection, Thiele's edition, p. 2, now perhaps more easily available in Steinberg's 1961 edition or in Erwin Leibfried and Josef Werli, Texte zur Theorie der Fabel (Stuttgart: Metzler, 1978), pp. 7-10.

16 See especially Ross Vander Meulen, "Luther's 'Betriegen zur Warheit' and Fables of Erasmus Alberus," The Germanic Review, 52 (1977), 5-15, in particular pp. 11-13.

17 Luthers Briefe, ed. Ludwig Enders, 7, 303; see also Werke, 50, 434.

18 Briefe, 7. 332 and 346.

19 Werke, 50, 434-435; see also Thiele's edition, p. iv.

20 From the Prologue, see Leibfried, p. 8.

21 Particularly the Steinhöwel edition. It seems that Luther used the bilingual edition, as there is direct evidence that he used the German edition and indirect evidence that he knew the Latin. See Carnes, "Heinrich Steinhöwel's Esopus," for various ideas on this subject. Note that all the fables in the collection stem from Steinhöwel's collection.

22 Leibfried, p. 9.

23 Von Both's dissertation provides a list of fables, sources and parallels in the writings of Luther, to which ought to be added some additional references found in the Compendium in Carnes, "Heinrich Steinhöwel's Esopus."

24 In 1889 Luther's autograph of this text was discovered in the Vatican library (codex Ottobonianus lat. 3029) by Richard Reitzenstein. A copy of this was reported to be in the University Library at Jena. This manuscript forms the basis for the Thiele edition.

25 See, among others, the Schirokauer article cited above, and Carnes, "Heinrich Steinhöwel's Esopus."

26 Pery, no 133 "Dog and Meat."

27 All of Luther's fables have a generalized topical label in the manuscript version and in the "finished" form: the first is labeled "Torheit," the second "Hass," the third "Untrew," and so on. This is curiously similar to the supposed headings under which the fables might have been found in their earliest "collections," i.e., a rhetorical handbook of sorts. See Ben Edwin Perry, "The Origin of the Epimythium."

28 This proverb is typical of Luther, who uses many proverbs again and again. See Werke, 19, 361, for instance, and Thiele, Luthers Sprichwörtersammlung (Weimar, 1900), no. 31.

29 This fable is one of the most common motifs found in Luther's works; see Both's dissertation, Appendix, and Luther, Werke, 7, 679.

30 Steinhöwel introduced the Italian Humanist fable tradition into Germany with Rinuccio d'Arezzo and perhaps Lorenzo Valla. Valla's fables are brought in with Sebastian Brant's expanded edition of Steinhöwel printed by Pforzheim in Basel in 1501. The others, Gregor Correr, Leonardo Dati and perhaps four others, remained unknown to most vernacular collections. Erasmus used a number of fables from these sources in the Adagia and some began to appear in the great Latin collections of 
Martin Dorp and Joachim Camerarius by the middle of the sixteenth century.

31 "Erzähltradition in homelitsichen Quellen," in Brückner's Volkserzählung und Reformation, pp. 705-756, especially 712-721.

32 Particularly pp. 705-711 and in Brückner's introduction. See also the Quellenverzeichnis, pp. 758791.

33 Mathesius, Korintherhomilien I (1590), quoted from Wolf, “Erzähltradition,” p. 717.

34 Editions in Christian Ludwig Küster's Hamburg dissertation: Illustrierte Aesop-Ausgaben des 15. und 16. Jahrhunderts (Hamburg: Aku-Fotodruck, 1970); modern editions by Heinrich Kurz (Leipzig: Weber, 1862) in two volumes and by Julius Tittmann in the series Deutsche Dichter des 16. Jahrhunderts, nos. 16-17 (Leipzig: Brockhaus, 1882).

35 From an edition so dated in the Special Collections of the Research Library at the University of California at Los Angeles. This edition seems to conform to Thoen, "Aesopus Dorpii," no. 57. See the listings of editions there.

36 Das Buch von der Tugend und Weissheit ..., ed. Wilhelm Braune in the Neudrucke deutscher Litteraturwerke des xvi. und xvii. Jahrhunderts series, nos. 104-107 (Halle/Salle: Niemeyer, 1892).

37 This idea is proposed by Vander Meulen in both the article cited above and in his very informative dissertation: "The Fables of Erasmus Alberus" (dissertation, University of Michigan, 1972).

38 Edited by Eli Sobel as no. 10 in the Folklore Studies Series from the University of California Press (Berkeley and Los Angeles, 1958).

39 See Perry, "The Origin of the Epimythium." It is clear that the emphasis was upon the paraenetic content, and not on either the structure or the quality of narrative as narrative alone. 